\title{
Сохранение редких видов растений в коллекции in vitro Волгоградского регионального ботанического сада
}

\section{Conservation of rare plant species in vitro collection of Volgograd regional botanical garden}

\author{
Малаева Е. В. ${ }^{1,2}$ \\ Malaeva E. V. ${ }^{1,2}$ \\ ${ }^{1}$ Волгоградский региональный ботанический сад, г. Волгоград, Россия. E-mail: e.malaeva@mail.ru \\ ${ }_{2}^{2}$ Волгоградский государственный соџиально-педагогический университет, г. Волгоград, Россия \\ ${ }^{1}$ Volgograd Regional Botanical Garden, Volgograd, Russia \\ ${ }^{2}$ Volgograd State Social and Pedagogical University, Volgograd, Russia
}

Peфepam. Наряду с традиционными способами сохранения растений ex situ все большее значение приобретает использование для этих целей культуры изолированных тканей и органов. Работа по созданию коллекции in vitro Волгоградским региональным ботаническим садом (ГБУ ВО «ВРБС») ведется с 2005 г. На данный момент коллекция редких растений in vitro содержит 50 видов, относящихся к 19 семействам. В коллекции in vitro ГБУ ВО «ВРБС» наиболее представлены редкие виды растений следующих семейств: Fabaceae Lindl., Brassicaceae Burnett., Caryophyllaceae Juss., Liliaceae Juss., Asteraceae Bercht. Et J. Presl., Iridaceae Juss. Разработка эффективных методов воспроизводства растений является основой работ по сохранению генофонда.

Ключевые слова. Биологическое разнообразие, Волгоградский региональный ботанический сад (ВРБС), генетические банки, редкие растения, in vitro.

Summary. The application of isolated plant tissue and organs is getting more actual along with traditional plant ex situ conservation methods. Work on creating of in vitro collection in the Volgograd regional botanical garden is conducted since 2005. The collection in vitro of rare species of Volgograd regional botanical garden includes 50 species and 19 families. The following families are the most representative in bank of rare plant species of Volgograd regional botanical garden: Fabaceae Lindl., Brassicaceae Burnett., Caryophyllaceae Juss., Liliaceae Juss., Asteraceae Bercht. et J. Presl., Iridaceae Juss. The development of plants' reproduction methods is the basis of gene pool conservation.

Key words. Biological diversity, Volgograd Regional Botanical Garden (VRBG), gene banks, rare plants, in vitro.

Введение в культуру растений природной флоры с целью сохранения их генофонда является одним из приоритетных направлений деятельности ботанических садов. В настоящее время для сохранения редких видов растений широкое применение получил метод культуры in vitro. Многие исследователи указывают на важнейшее значение использования биотехнологического метода, как дополнительного варианта сохранения видов ex situ, выступающего в качестве их страхового фонда (Камелин, 1997; Андреев, Горбунов, 2000; Benson at al, 2000).

Следует отметить, что исследования в области культуры ткани для решения проблем сохранения генофонда растений имеют свои особенности (Вечернина, 2006). Довольно часто они связаны с отсутствием возможности свободного выбора объекта, а также дефицитом исходного материала нужного растения. В связи с этим, при введении в культуру in vitro редких видов в качестве исходного материала предпочтительно использовать семена из природных популяций, поскольку, таким образом обеспечивается генетическое разнообразие видов (Ишмуратова, Зарипова, 2000; Молканова, 2017).

Работа по созданию коллекции in vitro ГБУ ВО «Волгоградский региональный ботанический сад» (ГБУ ВО «ВРБС») ведется с 2005 г. На данный момент коллекция редких растений in vitro содержит 50 видов, относящихся к 19 семействам. Максимально в коллекции in vitro представлены следую- 
щие семейства: Fabaceae - 18 \% (включает 9 видов данного семейства), Iridaceae - 14 \% (7 видов), Asteraceae - $10 \%$ (5 видов), Brassicaceae $-8 \%$ (4 вида), Caryophyllaceae - $8 \%$ (4 вида). Семейства Dioscoreaceae R. Br, Paeoniaceae L., Papaveraceae Juss. - по 2 вида. Остальные семейства представлены в коллекции менее чем $2 \%$ и насчитывают по одному виду (рис. 1).

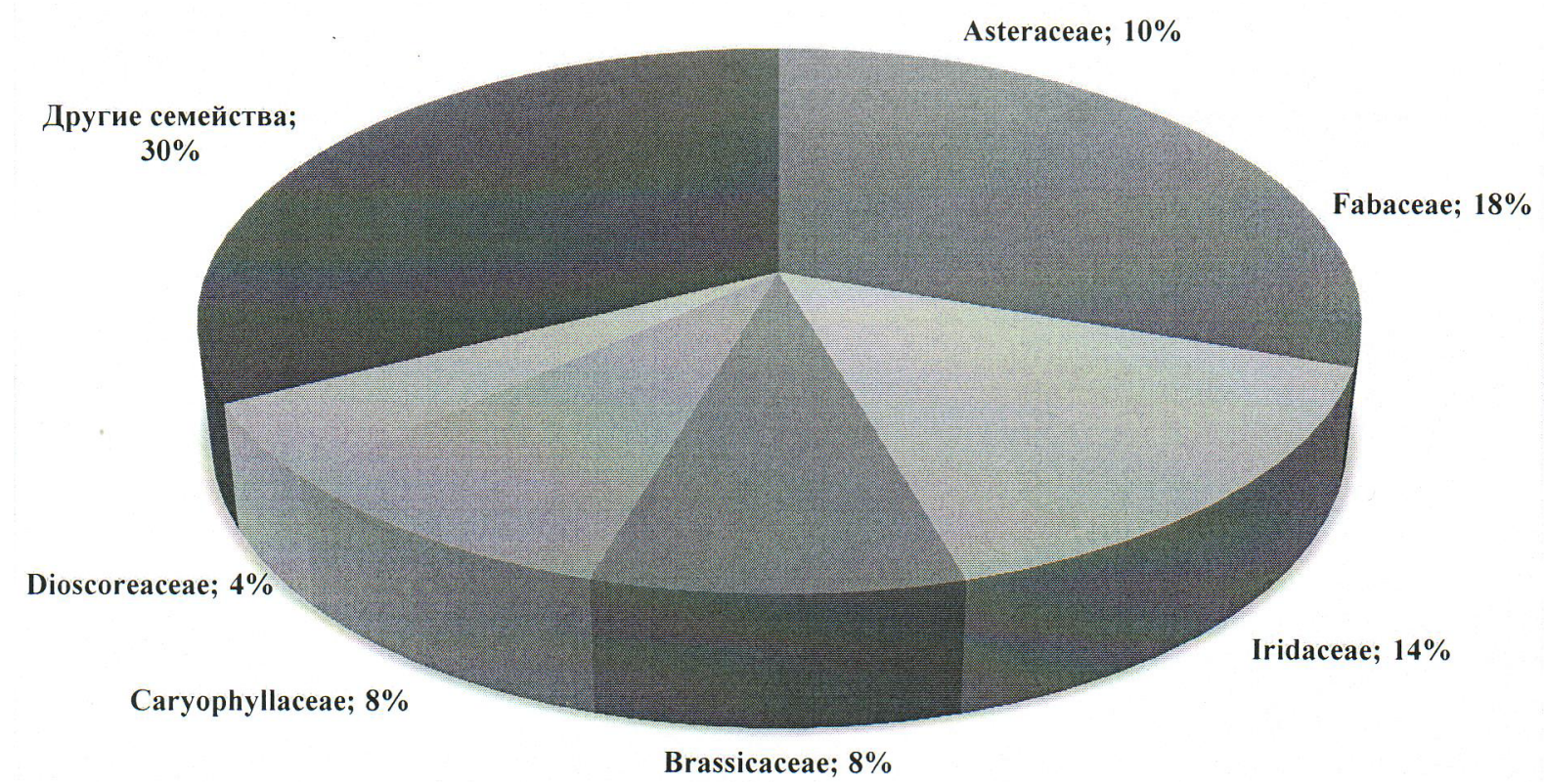

Рис. 1. Количественный состав семейств редких видов растений в коллекции in vitro ГБУ ВО «ВРБС».

В коллекции in vitro представлены редкие виды растений различных жизненных форм: прямостоячие кустарники (Calophaca wolgarica (L. fil.) DC, Genista tanaitica Smirn.), полукустарнички (Lepidium meyeri Claus., Silene cretacea Fisch, Hedysarum cretaceum Fisch.), стержнекорневые травянистые поликарпики (Matthiola fragrans Bunge , Hedysarum grandiflorum Pall., Astragalus dasyanthus Pall., короткокорневищные травянистые поликарпики (род Iris L.), луковичные и клубнелуковичные поликарпики (Bellevalia speciosa Woronow ex Grossh. (B. sarmatica (Gergi) Woronow), Allium regelianum A. Beck., Tulipa gesneriana L. (T. schrenkii Regel).

В качестве первичного материала для введения в культуру использовали в основном семена, собранные из природных мест произрастания редких видов растений (виды семейства Brassicaceae, Fabaceae, Caryophyllaceae и Asteraceae (табл. 1.); части почек возобновления с кусочком донца из луковицы (B. speciosa), сегменты листьев, частей околоцветника (Iris pumila L., Iris scariosa Willd. ex Link.) на разных стадиях развития (в фазе бутонизации или цветения). Для ряда видов (Aristolochia manshuriensis Kom., Artemisia salsoloides Willd., Parthenocissus tricuspidata (Siebold. et Zucc.) Planch.) в качестве первичных эксплантов брали апикальные и латеральные меристемы растений с интродукционного участка ГБУ ВО «ВРБС».

Методика исследований базировалась на общепринятых классических приемах с культурами изолированных тканей и органов растений (Бутенко, 1999). Семена предварительно обрабатывали 95 \%-ным этиловым спиртом в течение 50-60 секунд. В качестве стерилизатора использовали различные концентрации Хлорамина (действующее вещество - натриевая соль хлорамида бензосульфокислоты) и «Лизоформина 3000» (действующее вещество - глутаровый альдегид, глиоксаль и дидецилдиметиламмоний хлорид) с различной временной экспозицией. Методика по применению стерилизующего вещества - «Лизоформин 3000» устанавливалась опытным путем сотрудниками лаборатории биотехнологии ГБУ ВО «ВРБС».

После многократного промывания в стерильной дистиллированной воде семена высаживали на безгормональную питательную среду с минеральной основой по прописи Мурасиге-Скуга (Murashige, 
Skoog, 1962). При оценке оптимального режима стерилизации учитывали количество заросших и количество проросших семян. Проростки делили на фрагменты и пересаживали на модифицированные питательные среды для получения пролиферирующей культуры.

Таблица 1

Всхожесть семян редких видов растений в культуре in vitro

\begin{tabular}{|c|c|c|c|}
\hline Семейство & Вид & КК & проросших семян, \% \\
\hline Caryophyllaceae & Silena helmanii Claus & $\begin{array}{c}\text { КК ВО - 3a } \\
\text { КК РФ - } 3\end{array}$ & 80 \\
\hline Caryophyllaceae & Silena cretacea Fisch. ex Spreng. & $\begin{array}{c}\text { КК ВО - 3a } \\
\text { КК РФ - } 3\end{array}$ & 60 \\
\hline Fabaceae & Hedysarum. Grandiflorum Pall. & $\begin{array}{l}\text { КК ВО - 5б } \\
\text { КК РФ - } 3\end{array}$ & 50 \\
\hline Fabaceae & Hedysarum cretaceum Fisch. & $\begin{array}{l}\text { КК ВО - 3a } \\
\text { КК РФ - } 3\end{array}$ & 30 \\
\hline Fabaceae & Genista tanaitica P. Smirn. & $\begin{array}{l}\text { КК ВО - 3a } \\
\text { КК РФ - } 3\end{array}$ & 40 \\
\hline Fabaceae & Calophaca wolgarica (L. fil.)DC & $\begin{array}{l}\text { КК ВО - 3a } \\
\text { КК РФ - } 2\end{array}$ & 30 \\
\hline Brassicaceae & Crambe tataria Sebeok. & КК ВО - 3в & 40 \\
\hline Brassicaceae & Mathiola fragrans Bunge & $\begin{array}{l}\text { КК ВО - 5б } \\
\text { КК РФ - } 3\end{array}$ & 50 \\
\hline Brassicaceae & $\begin{array}{l}\text { Megacarpaea megalocarpa } \\
\text { (Fisch. ex DC.) B. Fedtsch. }\end{array}$ & КК ВО - 3г & 30 \\
\hline Asteraceae & Anthemis trotzkiana Claus & $\begin{array}{l}\text { КК ВО - 3в } \\
\text { КК РФ - } 3\end{array}$ & 40 \\
\hline Asteraceae & Serratula tanaitica P. Smirn. & $\begin{array}{c}\text { КК ВО - 3a } \\
\text { КК РФ - } 1 \\
\end{array}$ & 20 \\
\hline
\end{tabular}

Примечание: КК РФ (Красная книга Российской Федерации - перечень по состоянию на 2005 г.); КК ВО (Красная книга Волгоградской области - перечень по состоянию на 2017 г.); МО - (Виды растений, являющиеся объектами специального внимания и мониторинга на территории Волгоградской области).

В условиях in vitro растения культивировали в чашках Петри и биологических пробирках при освещении с интенсивностью 3-5 клк, при 16-часовом фотопериоде, температуре $24{ }^{\circ} \mathrm{C}$ и относительной влажности воздуха $70 \%$. Все опыты проводили трижды, повторность в каждом варианте 10-кратная. Оптимальным режимом стерилизации семян исследованных видов является 5 \% лизоформин, при этом время экспозиции составляет 7 мин.

Максимальный процент проросших семян наблюдали у представителей семейства Caryophyllaceae. Так, у смолевки Гельмана (S. helmanii) и смолевки меловой (S. cretacea) 80 и 60 \% соответственно. Процент всхожести у представителей семейства Fabaceae составил от 30-50 \%. У видов семейства Brassicaceae наибольший процент проросших семян при оптимальном режиме стерилизации наблюдали у левкоя душистого (M. fragrans) - 50 \%. Семена

крылоплодника большеплодного (M. megalocarpa) характеризовались растянутым периодом прорастания, достигая максимального значения - 30 \%. Для введения в культуру in vitro катрана татарского (C. tataria) весьма эффективным оказалось предварительное замачивание семян в 9 \% растворе перекиси водорода, при этом всхожесть составила 40 \%. У представителей семейства Asteraceae наблюдали невысокие показатели всхожести: пупавка Корнух-Троцкого (A. trotzkiana) - 40 \%, серпуха донская (S. tanaitica) $-20 \%$.

Особый интерес для размножения в культуре in vitro представляют некоторые виды семейства Fabaceae: травянистые многолетники H. grandiflorum и H. cretaceum - эндем Донецкого кряжа и юга Приволжской возвышенности; кустарничек C. wolgarica - эндем Восточного Причерноморья, Нижней 
Волги и Предкавказья; кустарник G. tanaitica - узкоареальный эндемик (Красная книга..., 2017). Все они занесены в Красную книгу РФ. Многие из них трудно размножаются традиционными способами, т. к. имеют стержневую корневую систему и для некоторых видов характерна твердосемянность.

Установлено, что темпы развития эксплантов при культивировании разных видов существенно различаются. Так если для G. tanaitica наиболее высокий коэффициент размножения наблюдался на этапе введения в культуру и при первых субкультивированиях, то для $H$. grandiflorum и $H$. cretaceum максимальный коэффициент размножения приходился на 4-6 пассаж.

Различным было и оптимальное время пассажа. Для $C$. wolgarica субкультивирование следует проводить через 30-35 дней, т. к. в дальнейшем увеличения коэффициента размножения не происходило и замедлялись темпы роста. Кроме того, у значительной части растений in vitro начинали подсыхать листья. Для H. grandiflorum и H. cretaceum время культивирования без пересадки составляет 50-70 дней и более.

Было изучено влияние различных концентраций цитокининов на пролиферацию. С помощью оптимизации гормонального состава среды удалось повысить коэффициент размножения $\mathrm{H}$. grandiflorum и H. cretaceum в два раза, а C. wolgarica и G. tanaitica в 4-5 раз.

При культивировании растений класса Однодольные мы использовали основы питательных сред Кнудсона (Кн), Гамбурга (B5) и Мурасиге - Скуга (МC) дополненные цитокининами и ауксинами в различных концентрациях $(0,1-0,5$ мг/л) и их сочетание.

Установлено, что длительное культивирование растений на средах, содержащих цитокинины приводило к появлению большого количества различных аномалий развития и, как следствие, остановке роста растений. В некоторых случаях отмечено появление морфогенного каллуса, образование которого ингибировало нормальное развитие растений, что согласуется с данными других исследователей.

На питательных средах, не содержащих фитогормонов отмечали равномерный рост растений. На этой питательной среде МС, при культивировании растений более месяца наблюдалось большое количество обводненных побегов и большое число отмерших листьев. На питательной среде Кн наблюдался замедленный, но равномерный рост растений, при этом через 1 месяц культивирования растения были нормальной морфологии и низким числом отмерших листьев.

На питательной среде МС (БАП 0,1+ИУК 0,1) развитие растений было динамичным, показатели длины первого листа были наибольшими из всех вариантов питательных сред, но и показатели развития нарушений в росте и развитии растений были одни из самых высоких.

В результате проведенных исследований установлено, что оптимальной питательной средой для рода Iris является питательная среда Кнудсона. На данной среде у растений наблюдается медленный равномерный рост, при этом количество аномальных и нежизнеспособных растений минимально, что в свою очередь позволяет сохранять коллекцию in vitro длительное время.

Результаты экспериментов по подбору сред на этапе укоренения показывают значительные отличия процента укоренения в зависимости, как от видовых особенностей редких и исчезающих видов, так и от концентрации ауксинов, применяемых для индукции ризогенеза.

Модельными объектами для проведения экспериментов по укоренению были выбраны представители семейства Brassicaceae. В ходе работы изучали влияние ИУК и ИМК на процесс ризогенеза. Укореняемые побеги L. meyeri высаживали на питательные среды, минеральную основу которых составляла полная и разбавленная вдвое модифицированная среда МС с добавлением 20 г/л сахарозы, 6,5 г/л агара и набора витаминов как в основной среде.

Наш опыт по укоренению редких видов растений показал, что при использование полной минеральной основы MS требуются более высокие концентрации ауксинов - от 1,0 мг/л. Использование обедненных питательных сред - Уайта, 1/2 MC позволяют снизить концентрацию ауксинов - от 0,3 до $0,5 \mathrm{мг} / л$.

При культивировании однодольных растений следующих семейств: Asphodelaceae Juss., Iridaceae, Hyacinthaceae L., Liliaceae Juss, Orchidaceae Juss, Melanthiaceae Batsch ex Borkh. на стадии собственно микроразмножение отмечали спонтанное образование корней около $90 \%$ на различных прописях питательных сред без добавления фитогормонов.

Выход адаптированных растений-регенерантов редких видов составил от30 до 50 \%. 
Таким образом, в результате исследований по стерилизации семян редких видов растений установлено влияние режимов стерилизации на сроки прорастания. Так, при увеличение времени экспозиции увеличивался процент стерильных семян, но повышался процент не проросших и растягивались сроки прорастания. Питательные среды, содержащие гормоны, оказывали угнетающие влияние на развитие проростков. Происходило появление аномально утолщенных проростков, в то время как на безгормональной среде формировались проростки нормальной морфологии.

В результате исследований модифицированы и адаптированы методики клонального микроразмножения некоторых редких и исчезающих видов растений. Установлено, что реализация морфогенетического потенциала у редких и исчезающих видов растений определяется видовыми особенностями исходных растений, типом экспланта, его физиологическим состоянием, составом питательных сред и условиями культивирования.

\section{ЛИТЕРАТУРА}

Андреев Л. Н., Горбунов Ю. Н. Сохранение редких и исчезающих растений ех situ: достижения и проблемы // Изучение и охрана разнообразия фауны, флоры и основных экосистем Евразии. Материалы Междунар. конф. M, 2000. - C. 19-23.

Бутенко P. Г. Биология клеток высших растений in vitro и биотехнологии на их основе: учебное пособие. М.: ФБК-Пресс, 1999. - 160 с.

Вечернина Н. $\boldsymbol{A}$. Сохранение биологического разнообразия редких, исчезающих видов, уникальных форм и сортов растений методами биотехнологии: автореф. дис. ... д-ра биол. наук. - Барнаул, 2006. -33 с.

Иимуратова М. М., Зарипова А. А. Особенности морфогенеза Polemonium caeruleum L. in vitro и in vivo // Растительные ресурсы, 2000. - Т. 36, вып. 3. - С. 106-115.

Камелин Р. В. Биотехнологическое разнообразие и интродукция растений //Растительные ресурсы, 1997. - Т. 33. - Вып. 3. - С. 1-11.

Красная книга Волгоградской области Т.2. Растения и другие организмы / Под ред. О. Г. Барановой, В. А. Сагалаева. - Воронеж: ООО «Издат-Принт», 2017. - 268 с.

Молканова О. И. Использование биотехнологических методов для размножения и сохранения редких видов растений // Бюл. ГБС, 2017. - №1(203). - С. 42-48.

Benson E. E. Danaher J. E., Pimbley I. M, Anderson C. T., Wake J. E., Daley S., Adams L. K. In vitro micropropagation of Primula scotica: a rare Scotish plant // Biodiversity and conservation, 2000. - Vol. 9. - P. 711-726.

Murashige T., Skoog F. A revised medium for rapid growth and bioassays with tobacco tissue cultures // Phsiol. plant., 1962. - Vol. 15, № 3. - P. 473-497. 